Article

\title{
Understanding Customer Experience and Satisfaction through Airline Passengers' Online Review
}

\author{
Hyun-Jeong Ban and Hak-Seon Kim * \\ School of Hospitality and Tourism Management, Kyungsung University, 309 Suyoungro, Nam-Gu, \\ Busan 48434, Korea \\ * Correspondence: kims@ks.ac.kr; Tel.: +82-51-663-4473
}

Received: 8 June 2019; Accepted: 18 July 2019; Published: 27 July 2019

\begin{abstract}
This study was conducted to understand customer experience and satisfaction through airline passengers' online review. To achieve the purpose of this study, the semantic network analysis was conducted qualitatively by collecting reviews in top 10 airlines selected by Skytrax (airlinequality.com). In addition, this study quantitatively identified the relationship among six evaluation factors (seat comfort, staff, food and beverage (F\&B), entertainment, ground service, and value for money), customer satisfaction and recommendation. This study collected 9632 reviews from the Skytrax. Through a CONCOR (CONvergence of iterated CORrelation) analysis, keywords were grouped into six clusters (seat comfort, staff, entertainment, ground service, value for money, and airline brand). Through the linear regression analysis, all evaluation factors except 'entertainment' factor significantly had impact on customer satisfaction and recommendation. These results showed that understanding online review can provide both academic implication and practical implication to develop sustainable strategy in the airline industry.
\end{abstract}

Keywords: customer experience; customer satisfaction; online review; skytrax; big data; semantic network analysis

\section{Introduction}

Due to fierce competition in the airline industry, the airline company needs to focus on the passenger's experience and satisfaction [1]. Customer feedback, in particular, is critical since it is an outcome measurement for business performance [2]. According to the international air transport association (IATA) [3], numbers of airline passengers were increasing by about $7 \%$ every year since 2015. However, the net profit per airline passenger was decreasing by $\$ 10$ for 2015, $\$ 9$ for 2016 and 2017, and it was estimated at only $\$ 7.4$ for 2018 . This is mainly due to intense competition, and also airline costs have been rising recently. The major expenses that affect companies in the airline industry are labor, fuel and other maintenance costs. The airline industry continues to be competitive, even though many people are traveling by aircraft. The Internet has also created greater price transparency, reducing margins [4].

Many studies have employed survey methods to measure service quality in the airline industry [2,5-9]. However, a few recent studies have highlighted the advantages of analyzing online review data for studying customers' satisfaction or their experience of the airline $[10,11]$. Online reviews are critical since it is a significant source for business growth, performance and improvement of customer experience, and allow airline companies to conduct two-way communication with airline passengers [12]. Moreover, electronic word of mouth (eWOM) shared by other airline passengers are considered trustworthy, fast and widespread [13].

In the previous study, the service quality of airline passenger has been measured in various ways. Elliott and Roach [5] used on-time performance, baggage handling, food quality, seat comfort, check-in 
service, and in-flight service as the criteria for evaluating airline service quality. Aksoy et al. [6] explored the differences in consumer expectations of airline services between passengers on the Turkish domestic airline and those on four foreign airlines on the same routes. They found that service expectations differed between the two groups. Gilbert and Wong [7] developed a 26-items questionnaire incorporating reliability, assurance, facilities, employees, flight patterns, customization, and responsiveness dimensions to measure and compare the differences in passengers' expectations of the desired airline service quality. Significant differences were found among passengers from different ethnic groups and among passengers who travel for different purposes. However, there were limited studies on the understanding experience and satisfaction of airline passengers using both qualitative and quantitative methods to analyze over 9000 online reviews.

The main contribution of this study is the understanding of customer experience and satisfaction through the airline passengers' online review. In order to reach the purpose, large amounts of customer reviews were collected from Skytrax (airlinequality.com). The analysis can be divided into two parts. One was to analyze the meaning of words extracted from the review data using the semantic network analysis by qualitative analysis. The other was conducted using the quantitative analysis method to understand relationships among six evaluation factors, customer satisfaction and recommendation.

\section{Literature Review}

\subsection{Customer Experience, Satisfaction and Online Review}

Customer satisfaction is a complex customer experience in the service industry, and can be defined as an evaluation on which the customers have experienced [14]. Understanding what consumers expect from a service industry is important in order to provide a standard of comparison against which consumers judge an organization's performance regarding the expectation [15]. Service quality can be defined as a consumer's overall impression of the relative efficiency of the organization [8]. In addition, customer satisfaction can be defined as experience made on the basis of a specific service encounter, and it is contributed to customer loyalty, repeat purchase, favorable word-of-mouth (WOM), and ultimately higher profitability [16].

The customer sets expectations for the product or service and these expectations are becoming the standard before purchasing. Once the product or service is used, the outcomes or perceptions are compared to pre-purchase expectations. Consumer generated content contains a variety of media forms and types [17]. Online reviews that reflect how customers explain and share their experiences in various forms are a valuable way of figuring out what customers think, and online platforms allow customers to share experience with information, opinions, and knowledge about products, services and brands [18]. Customers seek out a variety of information to be confident of their choices, thereby reducing the perceived risk [19]. Therefore, in this study, data was collected through the online review written by those who have already experienced it.

Due to the advance of technology, it is easy for customers to post their experience with products and services on the website [20]. It is especially relevant for service industries because of intangible characteristics of services. Many studies have demonstrated the strong impact of online customer reviews. For example, Dellarocas et al. [21] have demonstrated that online review metrics can accurately forecast movie revenue. Minnema et al. [22] have demonstrated that product returns have a strong relationship with online customer reviews and the effect of it needs to be considered. The number of reviews has grown exponentially over the past few decades, and the content of the reviews has had a significant impact on the repurchase of products [23]. Sotiriadis and van Zyl [24] found that online reviews and recommendations affect the decision making process of tourists towards tourism services and WOM has a significant impact on the subjective norms and attitudes towards an airline, and a customer's willingness to recommend. Therefore, the online review would be very useful for airlines to understand their diverse customer base in order to take service improvement strategies since airlines are inherently multicultural businesses. 


\subsection{Skytrax}

Skytrax is an airline quality assessment website that performs an online assessment after the customer directly used each airline [1]. Skytrax has worked for over 150 airlines across the globe, from the world's largest airlines through to small domestic carriers and it is a world-recognized brand that provides professional audit and service benchmarking programs for airlines on product and service quality. They employ professional auditors to assess the quality of the work done in an airline, both onboard and in the airport terminals. These evaluations are based on consistent standards [9].

The best airlines in the world highly recognize these quality awards presented by the Skytrax. When an airline is awarded a 'Skytrax star-ranking' or advances to a higher ranking, they immediately announce this news by publishing press releases and posting it on their websites' most visible spots. Both overall star rankings and detailed quality assessment results are publicly available on the Skytrax website [25]. This data has also been used in various academic studies as shown in Table 1.

Table 1. Academic studies using Skytrax (airlinequality.com).

\begin{tabular}{|c|c|c|}
\hline Author & Year & Title \\
\hline Adeniran, A., Fadare, S. O. [26] & 2018 & $\begin{array}{l}\text { Relationship between passengers' satisfaction and service } \\
\text { quality in Murtala Muhammed international airport, } \\
\text { Lagos, Nigeria }\end{array}$ \\
\hline Jeong, E. Y. [27] & 2017 & Analyze of airlines online-reviews: Focusing on Skytrax \\
\hline Yayla-Kullu, H. M., Tansitpong, P. [28] & 2013 & $\begin{array}{l}\text { A critical evaluation of US airlines' service quality } \\
\text { performance: Lower costs compared to satisfied customers }\end{array}$ \\
\hline Pérezgonzález, J. D., Gilbey, A. [29] & 2011 & Predicting Skytrax airport rankings from customer reviews \\
\hline $\begin{array}{l}\text { Lohmann, G., Albers, S., Koch, B., } \\
\text { Pavlovich, K. [30] }\end{array}$ & 2009 & $\begin{array}{l}\text { From hub to tourist destination-An explorative study of } \\
\text { Singapore and Dubai's aviation-based transformation }\end{array}$ \\
\hline Mason, K. J., Morrison, W. G. [31] & 2008 & $\begin{array}{l}\text { Towards a means of consistently comparing airline } \\
\text { business models with an application to the 'low cost' } \\
\text { airline sector }\end{array}$ \\
\hline Park, J. W., Robertson, R., Wu, C. L. [32] & 2006 & $\begin{array}{l}\text { The effects of individual dimensions of airline service } \\
\text { quality: Findings from Australian domestic air passengers }\end{array}$ \\
\hline Gillen, D., Lall, A. [33] & 2004 & $\begin{array}{l}\text { Competitive advantage of low-cost carriers: Some } \\
\text { implications for airports }\end{array}$ \\
\hline
\end{tabular}

\subsection{Big Data Analysis}

Big Data represents a new era in data exploration and utilization [34]. This is occurring because of new sources of data, and since the very beginning of the Internet, users have been keeping generating data on the Internet. The big data intensifies the need for sophisticated statistics and analytical skills. The big data technologies are providing unprecedented opportunities for statistical inference on massive analysis, but they also bring new challenges to be addressed, especially when compared to the analysis of carefully collected smaller data sets [16].

A semantic network analysis is becoming its own research paradigm as well as a method for analysis of the big data. The semantic network analysis is a method of identifying and analyzing relationships between words to describe a part of a connected network [35]. The semantic network analysis, as a method of qualitative textual analysis, provides a strong theoretical and methodological foundation with which to describe the semantic nature of the online tourism domain [36-38]. Centrality and proximity were employed to measure the structure of the semantic network and to compare the differences between two semantic structures in the Jo and Kim's [39] study. The similarities matrix generated in the text analysis can be used as input into multidimensional scaling to assess both the content and structure of the semantic network $[40,41]$.

While in this study, the similarities of the top 100 frequent words were conducted by CONCOR analysis, and the methodology for visualizing data are vital for understanding the semantic network of words [42]. The network can be visualized and verified, and the visual representation makes it easy 
to see at a glance the structure of the network or the associativity between nodes [43]. The approach and visualization for the semantic network analysis of this study was performed by Ucinet 6.0.

\section{Methodology}

\subsection{Data Collection}

The data was collected by web crawling, and the web crawler written in the Python 2.7. The server operating system is the Ubuntu 16.04 LTS from Skytrax (airlinequality.com). Several types of data were collected including the airline brand, type of aircraft, location of departure, destination, type of traveler, seat type, date flown, overall satisfaction rating along with additional ratings of seat comfort, staff, $\mathrm{F} \& \mathrm{~B}$, inflight entertainment, ground service, value for money, and the textual reviews with title and content with recommendation [25]. The overall satisfaction rating score was defined as the customer satisfaction in this study.

Initially, 62249 reviews were collected in 100 airlines, and there were 9632 reviews in the top 10 airlines presented by Skytrax (airlinequality.com). This study analyzes the top 10 airlines efficiently in terms of time and cost. The top 10 airlines are Singapore Airlines, Qatar Airways, All Nippon Airways, Emirates, EVA Air, Cathay Pacific Airways, Lufthansa, Hainan Airlines, Garuda Indonesia and Thai Airways. The period of collected reviews is from January 2011 to March 2019. The size of data is 9632 reviews and a total of 1,290,047 words are extracted [25].

The one-way analysis of variance (ANOVA) was used to analyze the mean difference between the average customer satisfaction with individual brands, and the method of Duncan was used for the post-hoc test. As shown in Table 2, Emirates has the largest number of reviews (1754) because it has the highest market share in the airline industry; it was followed by Qatar (1415), Lufthansa (1395), Cathay Pacific Airways (1173), and Singapore (1047).

Table 2. Reviews and average ratings according to airline brands.

\begin{tabular}{|c|c|c|c|c|c|}
\hline Rank & Brands & Reviews & Customer Satisfaction & Std. & Std. Error \\
\hline 1 & Singapore Airlines & 1047 & $7.501^{c}$ & 2.7292 & 0.0844 \\
\hline 2 & Qatar Airways & 1415 & $7.477^{\mathrm{c}}$ & 2.5277 & 0.0672 \\
\hline 3 & All Nippon Airways & 466 & $7.765^{b c}$ & 2.4989 & 0.1158 \\
\hline 4 & Emirates & 1754 & $5.766^{\mathrm{e}}$ & 3.2187 & 0.0768 \\
\hline 5 & EVA Air & 526 & $8.030^{a b}$ & 2.3012 & 0.1002 \\
\hline 6 & Cathay Pacific Airways & 1173 & $6.908^{d}$ & 2.9557 & 0.0863 \\
\hline 7 & Lufthansa & 1395 & $6.652^{d}$ & 3.0144 & 0.0806 \\
\hline 8 & Hainan Airlines & 347 & $8.238^{\mathrm{a}}$ & 2.2909 & 0.1228 \\
\hline 9 & Garuda Indonesia & 726 & $8.301^{\mathrm{a}}$ & 2.0979 & 0.0778 \\
\hline \multirow[t]{2}{*}{10} & Thai Airways & 783 & $6.796^{\mathrm{d}}$ & 2.8231 & 0.1009 \\
\hline & Total/Avg. & 9632 & 7.058 & 2.8972 & 0.0295 \\
\hline
\end{tabular}

The results of the analysis of variance among customer satisfaction with brands showed the following results, in decreasing order of satisfaction level: Garuda Indonesia (8.301), Hainan Airways (8.238), EVA Air (8.030), All Nippon Airways (7.765), Singapore Airlines (7.501), Qatar Airways (7.477), Cathay Pacific Airways (6.908), Thai Airways (6.796), Lufthansa (6.652) and Emirates (5.766). The results showed that there were significant differences between the customer satisfaction and numbers of reviews.

\subsection{Qualitative Data Analysis}

The analysis of this study, as shown in Figure 1, carried out the following process to identify the frequency and importance of keywords for the recognition of airline passengers [44]. The first stage was going to be collecting the review data online and refining the collected text. As for the 
data analysis, Ucinet 6.0 packaged with Netdraw, which is a visualization tool. The Netdraw is an illustration program to express how the frequent words are related and make an impact with certain interaction. It is mainly concentrated on the semantic network analysis about the extracted top 100 frequent keywords from raw data. After that, the centrality analysis of Freeman's degree has been worked out for refining the meanings of connection between the top 100 frequent words.

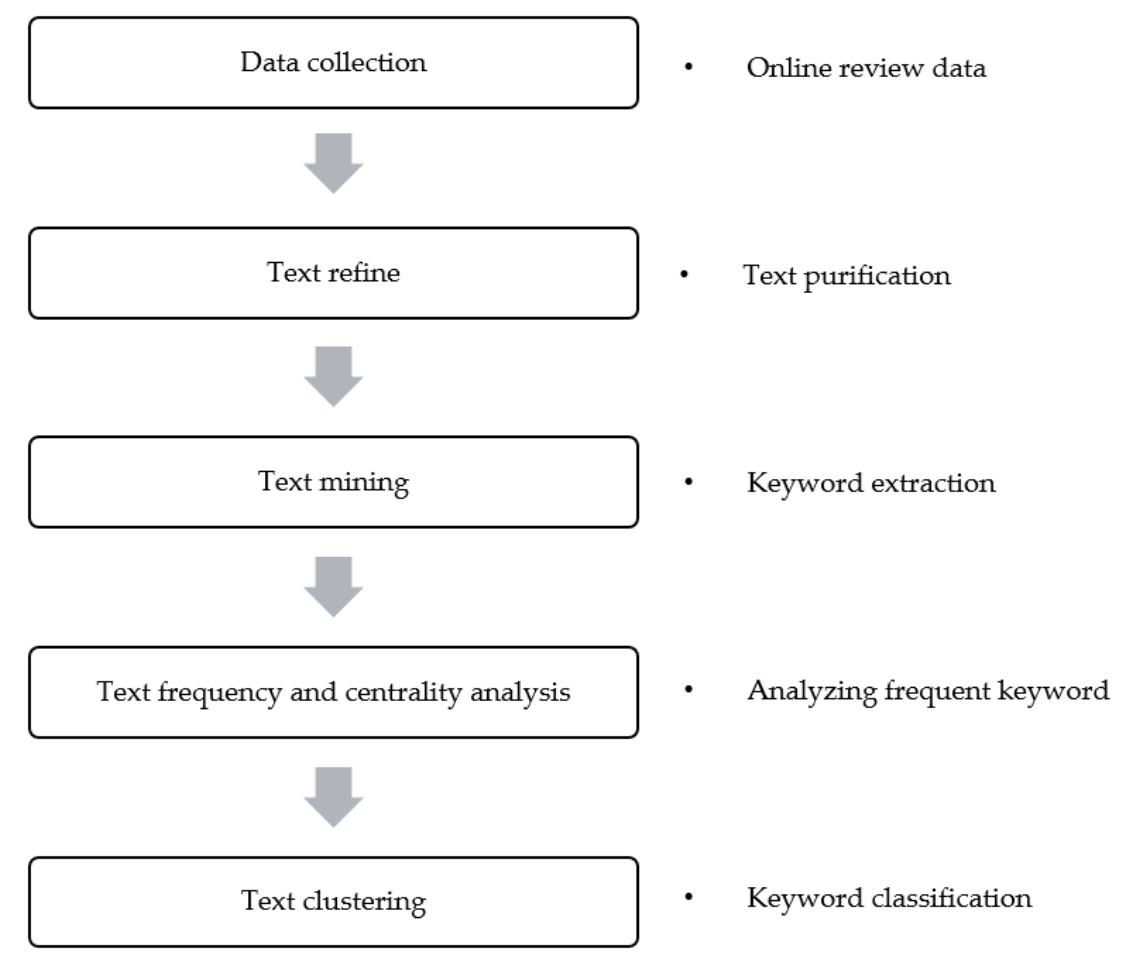

Figure 1. Qualitative research process.

According to Li and Sun [45], different measures such as centrality and proximity can be derived to measure the structure of the semantic network and to compare differences between two semantic structures. The last step of the analysis is CONCOR analysis. It helps segments of upper frequent words and visualizes the segmentation of higher frequent words so that frequently used words belong to any particular category and other words belong to any group.

\subsection{Quantitative Data Analysis}

For the quantitative analysis, the evaluation data on six factors (seat comfort, staff, F\&B, entertainment, ground service, value for money) with customer satisfaction and recommendation from Skytrax (airlinequality.com) were collected. Using the SPSS (IBM, Armonk, NY, USA) Statistics program, it conducted a linear regression analysis and verified the impact of each factor and the customer satisfaction. In addition, the relationship between customer satisfaction and recommendation was analyzed. For verification, a research model was established as shown in Figure 2.

There were thirteen hypotheses suggested as follows:

Hypotheses 1-1. Seat comfort positively influences the customer satisfaction of the airline.

Hypotheses 1-2. Staff positively influences the customer satisfaction of the airline.

Hypotheses 1-3. FEB positively influences the customer satisfaction of the airline.

Hypotheses 1-4. Entertainment positively influences the customer satisfaction of the airline.

Hypotheses 1-5. Ground service positively influences the customer satisfaction of the airline. 
Hypotheses 1-6. Value for money positively influences the customer satisfaction of the airline.

Hypotheses 2-1. Seat comfort positively influences the recommendation of the airline.

Hypotheses 2-2. Staff positively influences the recommendation of the airline.

Hypotheses 2-3. FEB positively influences the recommendation of the airline.

Hypotheses 2-4. Entertainment positively influences the recommendation of the airline.

Hypotheses 2-5. Ground service positively influences the recommendation of the airline.

Hypotheses 2-6. Value for money positively influences the recommendation of the airline.

Hypotheses 3. Customer satisfaction positively influences the recommendation of the airline.

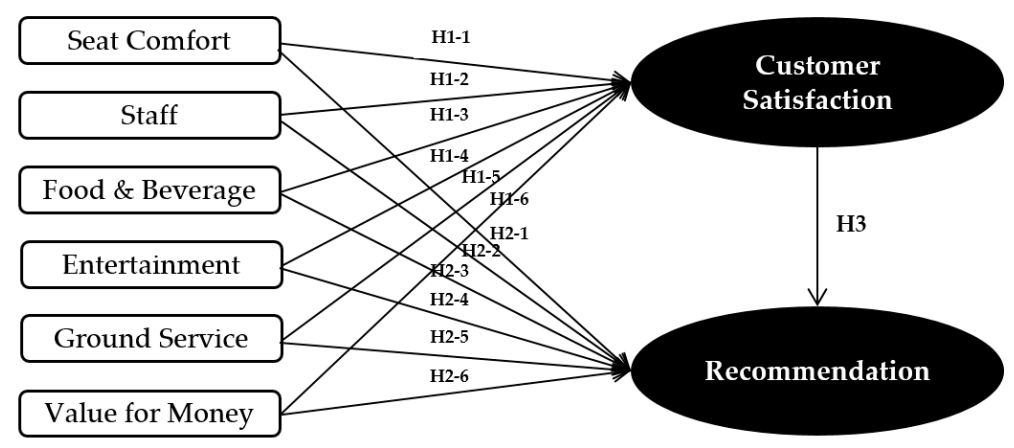

Figure 2. Quantitative research model.

\section{Results}

\subsection{Frequency Analysis}

To find the words most frequently used in customer reviews, Table 3 lists the top 100 frequent words associated with the airline experience and their corresponding frequency percentage. These words reflect the airline experience, including the airline brands such as 'emirates', 'lufthansa', 'qatar', 'cathay' and 'singapore' that have the frequency rank of 5, 7, 9, 10,11, and words related with seat comfort like 'seat', 'leg', 'legroom' and 'comfort' also possess high occurrence. The words describing F\&B, such as 'food', 'meal', 'drink' and 'breakfast' also belong to the top 100 frequency words. There are words for ground service such as 'lounge', 'luggage', 'ticket' and 'bag'. The words related with staff and service, such as 'crew', 'staff', 'attitude', 'smile' and 'cabin' appeared many times, and words in the value of money, such as 'money', 'price' and 'cost' were also included in the comments on their airline experience. The distribution of major upper words is shown in Figure 3, and the result of visualizing the network that reflects the frequency is Figure 4.

Table 3. Top 100 frequent words from the online airline review.

\begin{tabular}{|c|c|c|c|c|c|c|c|c|c|c|c|}
\hline Rank & Word & Freq & $\%$ & Rank & Word & Freq & $\%$ & Rank & Word & Freq & $\%$ \\
\hline 2 & review & 4225 & $19.05 \%$ & 36 & plane & 52 & $0.23 \%$ & 70 & frankfurt & 19 & $0.08 \%$ \\
\hline 4 & service & 915 & $4.12 \%$ & 38 & standard & 50 & $0.22 \%$ & 72 & notch & 19 & $0.08 \%$ \\
\hline 5 & emirate & 816 & $3.68 \%$ & 39 & journey & 48 & $0.21 \%$ & 73 & gate & 19 & $0.08 \%$ \\
\hline 6 & airline & 790 & $3.56 \%$ & 40 & aircraft & 47 & $0.21 \%$ & 74 & room & 19 & $0.08 \%$ \\
\hline 9 & cathay & 562 & $2.53 \%$ & 43 & money & 40 & $0.18 \%$ & 77 & wine & 18 & $0.08 \%$ \\
\hline 10 & qatar & 555 & $2.50 \%$ & 44 & drink & 40 & $0.18 \%$ & 78 & baggage & 18 & $0.08 \%$ \\
\hline 11 & singapore & 491 & $2.21 \%$ & 45 & check & 39 & $0.17 \%$ & 79 & job & 17 & $0.07 \%$ \\
\hline 12 & crew & 458 & $2.06 \%$ & 46 & value & 37 & $0.16 \%$ & 80 & movie & 17 & $0.07 \%$ \\
\hline 13 & experience & 408 & $1.84 \%$ & 47 & expectation & 33 & $0.14 \%$ & 81 & system & 17 & $0.07 \%$ \\
\hline
\end{tabular}


Table 3. Cont.

\begin{tabular}{|c|c|c|c|c|c|c|c|c|c|c|c|}
\hline Rank & Word & Freq & $\%$ & Rank & Word & Freq & $\%$ & Rank & Word & Freq & $\%$ \\
\hline 15 & seat & 352 & $1.58 \%$ & 49 & way & 32 & $0.14 \%$ & 83 & rate & 17 & $0.07 \%$ \\
\hline 17 & air & 337 & $1.52 \%$ & 51 & leg & 30 & $0.13 \%$ & 85 & future & 16 & $0.07 \%$ \\
\hline 18 & eva & 321 & $1.44 \%$ & 52 & premium & 30 & $0.13 \%$ & 86 & route & 16 & $0.07 \%$ \\
\hline 19 & cabin & 319 & $1.43 \%$ & 53 & space & 29 & $0.13 \%$ & 87 & wifi & 15 & $0.06 \%$ \\
\hline 22 & food & 222 & $1.00 \%$ & 56 & onboard & 28 & $0.12 \%$ & 90 & upgrade & 15 & $0.06 \%$ \\
\hline 23 & class & 154 & $0.69 \%$ & 57 & a380 & 26 & $0.11 \%$ & 91 & kind & 15 & $0.06 \%$ \\
\hline 24 & meal & 116 & $0.52 \%$ & 58 & level & 26 & $0.11 \%$ & 92 & option & 15 & $0.06 \%$ \\
\hline 25 & economy & 111 & $0.50 \%$ & 59 & dubai & 24 & $0.10 \%$ & 93 & turn & 15 & $0.06 \%$ \\
\hline 26 & time & 102 & $0.46 \%$ & 60 & a350 & 24 & $0.10 \%$ & 94 & selection & 14 & $0.06 \%$ \\
\hline 31 & inflight & 64 & $0.28 \%$ & 65 & lay & 22 & $0.09 \%$ & 99 & home & 13 & $0.05 \%$ \\
\hline 32 & trip & 63 & $0.28 \%$ & 66 & bag & 21 & $0.09 \%$ & 100 & people & 13 & $0.05 \%$ \\
\hline 33 & passenger & 57 & $0.25 \%$ & 67 & breakfast & 21 & $0.09 \%$ & & & & \\
\hline 34 & star & 54 & $0.24 \%$ & 68 & care & 21 & $0.09 \%$ & & & & \\
\hline
\end{tabular}

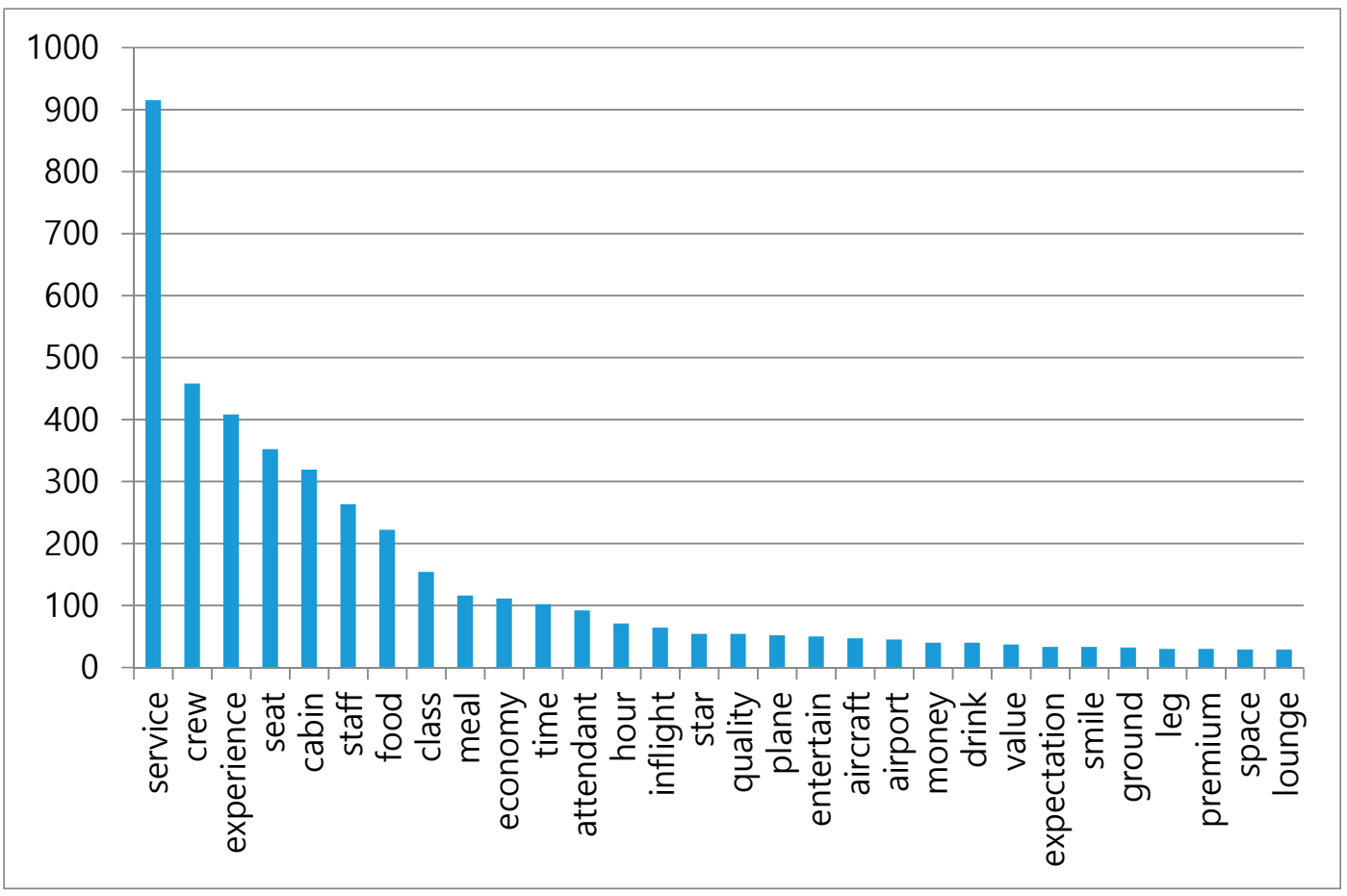

Figure 3. Distribution of major 30 words frequency. 


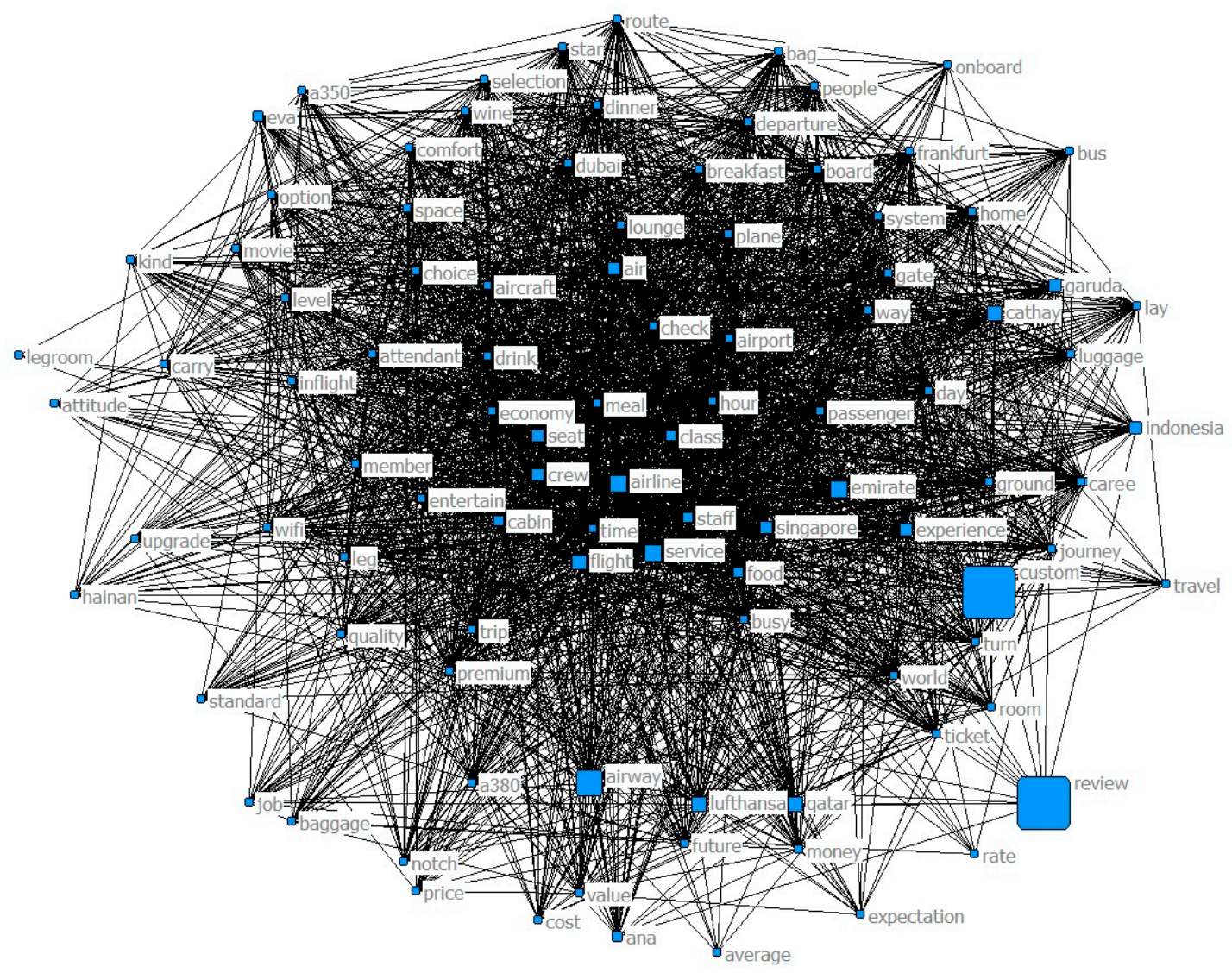

Figure 4. Keywords visualization of network analysis.

\subsection{Semantic Network Analysis}

The semantic network analysis identifies the relationship between words and expresses the connection between them. The centrality and CONCOR analysis of keywords were performed for the semantic network analysis. In the review of airlines, among the top 100 frequent words, the results of an analysis of the degree and eigenvector centrality of the words are described in Table 4.

The degree centrality is a simple centrality measure that counts how many neighbors a node has, and refers to the degree to which a word has many connections and becomes central, and the more connections it has, the greater its impact on other words, the more dominant it can be [46]. The eigenvector centrality extends the concept of connective centrality by considering not only the number of words connected, but also how important a connected relationship is. Thus, prestige is a useful indicator for finding the most influential central node in the network [47]. It is sometimes used to measure a node's influence in the network. It performs matrix calculations to determine adjustments.

The result is that words related with airline brands recorded a high rank in degree centrality, such as 'singapore', 'emirates', 'qatar', 'cathay' and 'lufthansa'. However, words related to airline brands have a low rank in the eigenvector centrality. The words related with staff, such as 'crew', 'attendant' and 'service' were frequently found in the online review. However, those words are not significantly connected with other words, according to the degree and eigenvector centrality analysis. In addition, 'class' and 'economy' have recorded a higher rank in degree centrality than frequency and eigenvector centrality. 'money', 'value' and 'expectation' are frequently found but they are not centralized words. 
Table 4. Comparison of keywords frequency and centrality analysis.

\begin{tabular}{|c|c|c|c|c|c|c|c|c|c|c|c|c|c|}
\hline & \multicolumn{2}{|c|}{ Frequency } & \multicolumn{2}{|c|}{ Degree } & \multicolumn{2}{|c|}{ Eigenvector } & & \multicolumn{2}{|c|}{ Frequency } & \multicolumn{2}{|c|}{ Degree } & \multicolumn{2}{|c|}{ Eigenvector } \\
\hline & Freq & Rank & Coef. & Rank & Coef. & Rank & & Freq & Rank & Coef. & Rank & Coef. & Rank \\
\hline custom & 4308 & 1 & 2.645 & 1 & 0.610 & 1 & time & 102 & 26 & 0.318 & 15 & 0.004 & 20 \\
\hline airway & 1747 & 3 & 1.144 & 3 & 0.365 & 3 & hainan & 99 & 28 & 0.073 & 46 & 0.020 & 15 \\
\hline service & 915 & 4 & 0.388 & 10 & 0.009 & 17 & attendant & 92 & 29 & 0.062 & 50 & 0.001 & 33 \\
\hline emirate & 816 & 5 & 0.450 & 7 & 0.141 & 4 & hour & 71 & 30 & 0.254 & 21 & 0.003 & 25 \\
\hline lufthansa & 694 & 7 & 0.333 & 12 & 0.126 & 7 & trip & 63 & 32 & 0.047 & 60 & 0.001 & 34 \\
\hline flight & 633 & 8 & 0.723 & 4 & 0.010 & 16 & passenger & 57 & 33 & 0.226 & 24 & 0.003 & 26 \\
\hline cathay & 562 & 9 & 0.401 & 9 & 0.134 & 6 & star & 54 & 34 & 0.032 & 70 & 0.000 & 64 \\
\hline qatar & 555 & 10 & 0.414 & 8 & 0.139 & 5 & quality & 54 & 35 & 0.055 & 55 & 0.001 & 35 \\
\hline singapore & 491 & 11 & 0.513 & 6 & 0.100 & 9 & plane & 52 & 36 & 0.132 & 30 & 0.001 & 36 \\
\hline crew & 458 & 12 & 0.322 & 13 & 0.003 & 21 & entertain & 50 & 37 & 0.087 & 41 & 0.001 & 37 \\
\hline air & 337 & 17 & 0.308 & 16 & 0.066 & 13 & choice & 42 & 42 & 0.108 & 34 & 0.001 & 39 \\
\hline eva & 321 & 18 & 0.247 & 22 & 0.065 & 14 & money & 43 & 43 & 0.029 & 73 & 0.000 & 67 \\
\hline cabin & 319 & 19 & 0.288 & 19 & 0.003 & 22 & drink & 44 & 44 & 0.129 & 32 & 0.001 & 40 \\
\hline ana & 298 & 20 & 0.242 & 23 & 0.072 & 12 & check & 45 & 45 & 0.098 & 35 & 0.001 & 41 \\
\hline staff & 263 & 21 & 0.141 & 29 & 0.002 & 27 & value & 46 & 46 & 0.016 & 85 & 0.000 & 68 \\
\hline food & 222 & 22 & 0.171 & 27 & 0.002 & 28 & expectation & 47 & 47 & 0.005 & 97 & 0.000 & 69 \\
\hline class & 154 & 23 & 0.320 & 14 & 0.003 & 23 & smile & 48 & 48 & 0.020 & 80 & 0.000 & 70 \\
\hline meal & 116 & 24 & 0.214 & 25 & 0.003 & 24 & way & 49 & 49 & 0.063 & 49 & 0.001 & 42 \\
\hline economy & 111 & 25 & 0.292 & 18 & 0.004 & 19 & ground & 50 & 50 & 0.060 & 52 & 0.001 & 43 \\
\hline
\end{tabular}

The CONCOR analysis analyzes the connection of the relationship and patterns between words to see their similarity, and the greater the similarity of the connection relationship patterns, the greater the degree of structural equivalence of the two words. It forms clusters that include keywords with similarities [10]. One of the most natural methods is the cluster analysis, which is a statistical technique that binds them into similarity groups based on interrelationships [48]. In other words, the CONCOR analysis is a method of repeatedly analyzing correlations to find appropriate levels of similarity groups. This study identifies the blocks of nodes according to the correlation coefficient of the matrices of the concurrent keywords and forms clusters that include keywords with similarities [18]. The keywords extracted from the frequency histogram according to the frequency ranking were used and a [keywords $\times$ keywords] matrix were constructed. To visualize the analysis results, NetDraw in UCINET 6.0 program was used. The nodes are presented as blue squares and their sizes indicate their frequency; the network shows the connectivity between them.

The result of the CONCOR analysis has been shown in Figure 5 with visibility. There are six groups that were intricately interwoven with each other. After looking at the words in the group, the group was named as seat comfort, staff, entertainment, airline brand, value for money and ground service. Interestingly, the CONCOR results were very similar to the evaluation factors (seat comfort, staff, F\&B, entertainment, ground service and value for money) presented by Skytrax (airlinequality.com). 


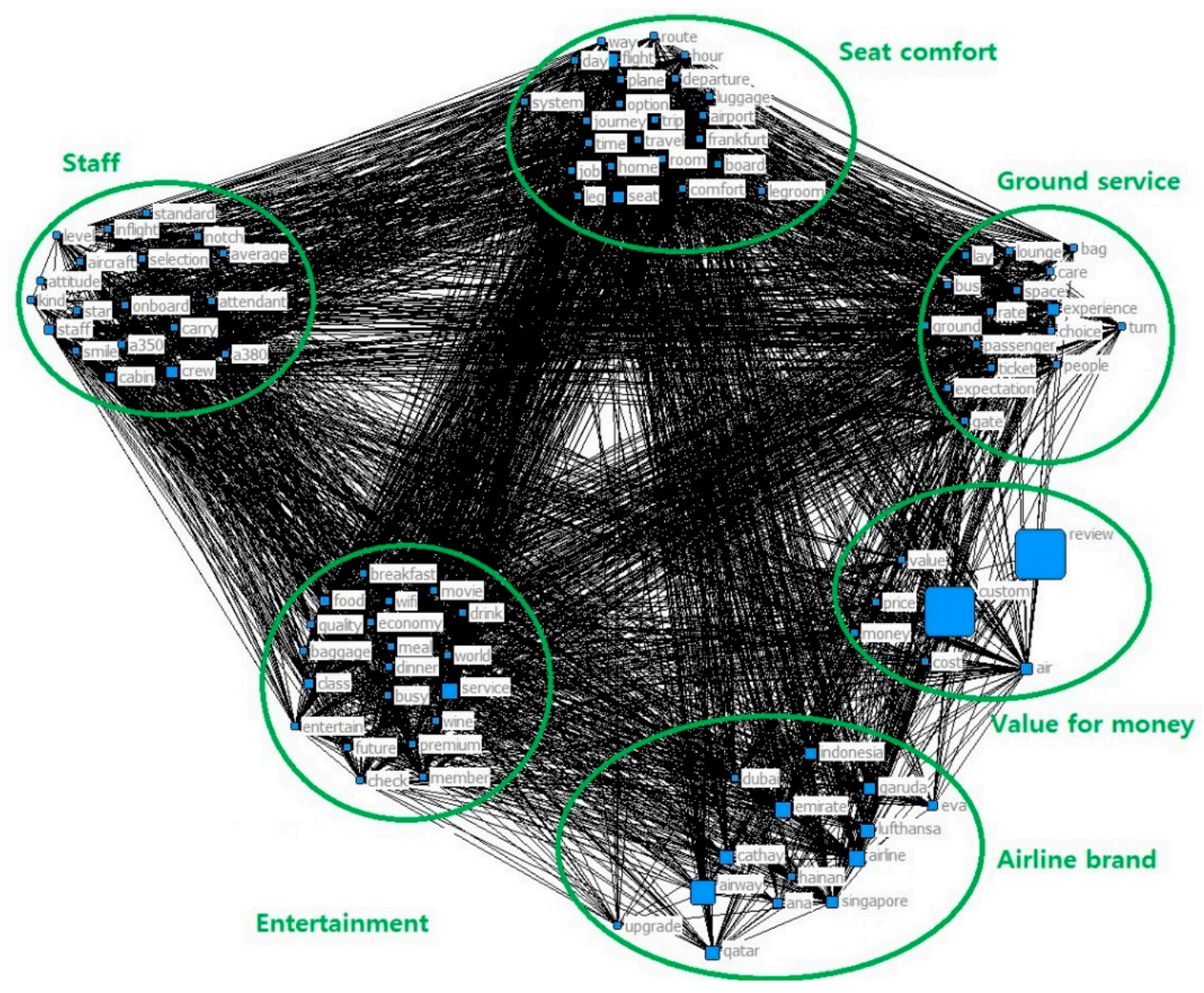

Figure 5. Visualization of CONvergence of iterated CORrelation (CONCOR) analysis.

To make it easier to see which words belong to each group, the words grouped in the cluster and the ones to be noted are listed in Table 5. As shown in Table 5, the group name was chosen as follows considering the characteristics of the words. Airline brand segmentation refers to the airline brand, which is in the top 10 airlines. The Thai Airways is the only airline company, which did not appear in the airline brand group. It means that the Thai Airways is not in the top 100 frequent words. The group of seat comfort has 'hour', 'comfort', 'legroom', 'time', 'seat', 'route', 'plane' and 'room'.

The entertainment group contained two concepts. One is F\&B, and the other one is entertainment activity. There are 'food', 'meal', 'breakfast', 'drink', 'dinner' and 'wine' for eating and drinking. However, 'entertain', 'premium', 'economy' and 'class' could be related to activities, therefore there are no other words for actual activity except 'movie'. In the group of staff, there were 'smile' and 'kind', which is directly connected with service attitude. So, 'smile' and 'kind' can describe the service staff working in the top 10 airlines. The other interesting word is 'bus' in the group of ground service. 'ticket', 'lounge' and 'bag' are usually represented by ground service. However, the number of flights, airlines is diverse, and therefore the airport is crowded, so passengers need to get on the plane using a bus. Therefore, airline passengers may feel uncomfortable about boarding the plane. It means transportation for boarding also can affect the satisfaction, because passengers wrote down their airline experience mentioning this segmentation. In addition, this service can improve passengers' perceived achievement and power compared to others [49]. 
Table 5. Result of CONCOR analysis.

\begin{tabular}{|c|c|c|}
\hline & Extracted Words & Significant Words \\
\hline Seat Comfort & $\begin{array}{c}\text { flight/seat/time/hour/way/leg/plane/journey/ } \\
\text { legroom/comfort/luggage/board/day/system/ } \\
\text { room/trip/airport/frankfurt/route/option/ } \\
\text { departure/travel/job/home }\end{array}$ & $\begin{array}{l}\text { flight/seat/time/hour/way/leg/plane/journey/ } \\
\text { legroom/comfort/board/room/route/option }\end{array}$ \\
\hline Staff & $\begin{array}{c}\text { crew/cabin/staff/attendant/inflight/star/standard/ } \\
\text { aircraft/smile/onboard/a380/level/a350/ } \\
\text { notch/attitude/kind/selection/average/carry }\end{array}$ & $\begin{array}{c}\text { crew/cabin/staff/attendant/star/standard/ } \\
\text { smile/level/notch/attitude/kind/ } \\
\text { selection/average/carry }\end{array}$ \\
\hline Entertainment & $\begin{array}{c}\text { service/food/class/meal/economy/busy/quality/ } \\
\text { entertain/drink/ } \\
\text { check/premium/breakfast/world/wine/ } \\
\text { baggage/movie/dinner/future/member }\end{array}$ & $\begin{array}{c}\text { service/food/class/meal/economy/quality/ } \\
\text { entertain/drink/premium/breakfast/ } \\
\text { wine/movie/dinner }\end{array}$ \\
\hline Ground Service & $\begin{array}{c}\text { experience/choice/passenger/lounge/space/ } \\
\text { bag/care/lay/ground/rate/people/turn/gate/ } \\
\text { expectation/bus/ticket }\end{array}$ & $\begin{array}{l}\text { experience/passenger/lounge/space/bag/ } \\
\text { lay/ground/date/bus/ticket }\end{array}$ \\
\hline Value for Money & custom/review/air/value/price/money/cost & custom/money/value/price/cost \\
\hline Airline Brand & $\begin{array}{c}\text { airway/emirates/airline/lufthansa/cathay/qatar/ } \\
\text { singapore/garuda/indonesia/eva/ana/ } \\
\text { hainan/dubai/upgrade }\end{array}$ & $\begin{array}{l}\text { airway/emirates/airline/lufthansa/cathay/ } \\
\text { qatar/singapore/garuda/indonesia/eva/ } \\
\text { ana/hainan/dubai }\end{array}$ \\
\hline
\end{tabular}

\subsection{Linear Regression Analysis}

Table 6 displays the results of the linear regression analysis with 'Customer Satisfaction (CS)' as the dependent variable and it has six independent variables: 'Seat comfort (SC)', 'Staff (S)', 'Food \& Beverage (FB)', 'Entertainment (E)', 'Ground service (GS)' and 'Value for money (VM)'. The overall variance explained by the six predictors was $76.2 \%\left(R^{2}=0.762\right)$ and the standard error of the estimated value was calculated as 1.412. All factors are significant at the $p<0.001$ level except 'Entertainment (E, $\beta=-0.003, p=0.617$ ' factor. Five factors are positively related to the customer satisfaction, according to their standardized coefficient values: 'Seat comfort (SC, $\beta=0.080, p<0.001$ )', 'Staff (S, $\beta=0.176$, $p<0.001$ )', 'Food \& beverage (FB, $\beta=-0.102, p<0.001$ )', 'Value for money (VM, $\beta=0.603, p<0.001$ ) and 'Ground service (GS, $\beta=0.042, p<0.001$ )'. Therefore, hypothesis $1-1,1-2,1-3,1-5$ and 1-6 were supported, however hypothesis 1-4 was rejected. In order to estimate the possible correlations among the predictors, a multicollinearity statistic was conducted. The tolerance level is less than 10.00 , and the variance inflation factor (VIF) of the predictors were between 10.00 and 100.00, respectively, that is, the predictors were not significantly correlated to each other. Therefore, based on unstandardized $\beta$, the regression equation can be expressed as:

$$
\mathrm{CS}=-0.843+0.172 \mathrm{SC}^{*}+0.349 \mathrm{~S}^{*}+0.203 \mathrm{FB}^{*}-0.005 \mathrm{E}+0.058 \mathrm{GS}^{*}+1.347 \mathrm{VM}^{*}
$$

The 'Value for money' factor holds the highest standardized coefficients, which mean this experience aspect of the passenger is the most important factor associated with customer satisfaction significantly. Reviews like "It's value for money and it's best if you compare to other airlines based on travel duration and price." and "First time trying the premium economy of Singapore Airlines, must I say I was really impressed by the offering and the value for money." are related to the airline experience based upon 'Value for money' attributes. 
Table 6. Results of linear regression analysis (Dependent variable: Customer Satisfaction).

\begin{tabular}{|c|c|c|c|c|c|c|c|}
\hline \multirow{2}{*}{ Model } & \multicolumn{2}{|c|}{$\begin{array}{l}\text { Unstandardized } \\
\text { Coefficient }\end{array}$} & \multirow{2}{*}{$\begin{array}{c}\begin{array}{c}\text { Standardized } \\
\text { Coefficient }\end{array} \\
\text { Beta }\end{array}$} & \multirow[t]{2}{*}{$t$} & \multirow[t]{2}{*}{ Sig. } & \multicolumn{2}{|c|}{ Collinearity Statistics } \\
\hline & B & Std. Error & & & & Tolerance & VIF \\
\hline (Constant) & -0.843 & 0.049 & & -17.253 & 0.000 & & \\
\hline Seat Comfort (SC) & 0.172 & 0.016 & 0.080 & 10.828 & 0.000 & 0.449 & 2.227 \\
\hline Staff (S) & 0.349 & 0.016 & 0.176 & 21.643 & 0.000 & 0.375 & 2.670 \\
\hline Food \& Beverage (FB) & 0.203 & 0.016 & 0.102 & 12.420 & 0.000 & 0.366 & 2.733 \\
\hline Entertainment (E) & -0.005 & 0.011 & -0.003 & -0.501 & 0.617 & 0.676 & 1.480 \\
\hline Ground Service (GS) & 0.058 & 0.007 & 0.042 & 8.026 & 0.000 & 0.890 & 1.123 \\
\hline Value for money (VM) & 1.347 & 0.016 & 0.603 & 84.612 & 0.000 & 0.486 & 2.057 \\
\hline
\end{tabular}

* Dependent variable: Customer Satisfaction (CS); $\mathrm{R}^{2}=0.762 ; \mathrm{F}=5147.275 ; p<0.001$.

Table 7 displays the results of the linear regression analysis with 'Recommendation (R)' as the dependent variable and it has six independent variables: 'Seat comfort (SC)', 'Staff (S)', 'Food \& Beverage (FB)', 'Entertainment (E)', 'Ground service (GS)' and 'Value for money (VM)'. The overall variance explained by the six predictors was $60.5 \%\left(R^{2}=0.605\right)$ and the standard error of the estimated value was calculated as 0.2773 . All factors are significant at the $p<0.001$ level except 'Entertainment $(\mathrm{E}, \beta=-0.015, p=0.053$ )' factor. Five factors are positively related to the recommendation, according to their standardized coefficient values: 'Seat comfort (SC, $\beta=0.045, p<0.05$ )', 'Staff $(\mathrm{S}, \beta=0.197$, $p<0.05)^{\prime}$, 'Food \& beverage (FB, $\beta=0.040, p<0.05$ )', 'Ground service (GS, $\beta=0.014, \mathrm{p}<0.05$ ) and 'Value for money (VM, $\beta=0.577, p<0.05$ )' 0 . Therefore, hypothesis 2-1, 2-2, 2-3, 2-5 and 2-6 was supported, however hypothesis $2-4$ was rejected. Therefore, based on unstandardized $\beta$, the regression equation can be expressed as:

$$
R=-0.325+0.015 \mathrm{SC}^{*}+0.059 \mathrm{~S}^{*}+0.012 \mathrm{FB}^{*}-0.004 \mathrm{E}+0.003 \mathrm{GS}^{*}+0.196 \mathrm{VM}^{*}
$$

Table 7. Results of linear regression analysis (Dependent variable: Recommendation).

\begin{tabular}{|c|c|c|c|c|c|c|c|}
\hline \multirow{2}{*}{ Model } & \multicolumn{2}{|c|}{$\begin{array}{l}\text { Unstandardized } \\
\text { Coefficient }\end{array}$} & \multirow{2}{*}{$\begin{array}{c}\begin{array}{c}\text { Standardized } \\
\text { Coefficient }\end{array} \\
\text { Beta }\end{array}$} & \multirow[t]{2}{*}{$t$} & \multirow{2}{*}{ Sig. } & \multicolumn{2}{|c|}{ Collinearity Statistics } \\
\hline & B & Std. Error & & & & Tolerance & VIF \\
\hline (Constant) & -0.325 & 0.010 & & -33.886 & 0.000 & & \\
\hline Seat Comfort (SC) & 0.015 & 0.003 & 0.045 & 4.4741 & 0.000 & 0.449 & 2.227 \\
\hline Staff $(S)$ & 0.059 & 0.003 & 0.197 & 18.794 & 0.000 & 0.375 & 2.670 \\
\hline Food \& Beverage (FB) & 0.012 & 0.003 & 0.040 & 3.807 & 0.000 & 0.366 & 2.733 \\
\hline Entertainment (E) & -0.004 & 0.002 & -0.015 & -1.936 & 0.053 & 0.676 & 1.480 \\
\hline Ground Service (GS) & 0.003 & 0.001 & 0.014 & 2.032 & 0.042 & 0.890 & 1.123 \\
\hline Value for Money (VM) & 0.196 & 0.003 & 0.577 & 62.722 & 0.000 & 0.486 & 2.057 \\
\hline
\end{tabular}

${ }^{*}$ Dependent variable: Recommendation $(\mathrm{R}) ; \mathrm{R}^{2}=0.605 ; \mathrm{F}=2451.601 ; p<0.001$

To verify the part corresponding to hypothesis 3, the third linear regression analysis was performed. The result is shown in Table 8 with a recommendation as the dependent variable and it has independent variables as customer satisfaction. The overall variance explained by the predictor was $69.4 \%\left(R^{2}=0.694\right)$ and the standard error of the estimated value was calculated as 0.244 . The customer satisfaction is significant and positively related to the recommendation, according to their standardized coefficient values: $\beta=0.833, p<0.001$ ). Therefore, hypothesis 3 was supported. 
Table 8. Results of linear regression (Dependent variable: Recommendation).

\begin{tabular}{|c|c|c|c|c|c|}
\hline \multirow{2}{*}{ Model } & \multicolumn{2}{|c|}{ Unstandardized Coefficient } & \multirow{2}{*}{$\begin{array}{c}\text { Standardized } \\
\text { Coefficient }\end{array}$} & \multirow[t]{2}{*}{$t$} & \multirow[t]{2}{*}{ Sig. } \\
\hline & B & Std. Error & & & \\
\hline (Constant) & -0.158 & 0.007 & & -24.173 & 0.000 \\
\hline Customer Satisfaction (CS) & 0.127 & 0.001 & 0.833 & 147.592 & 0.000 \\
\hline
\end{tabular}

* Dependent variable: Recommendation(R); $\mathrm{R}^{2}=0.694 ; \mathrm{F}=21783.469 ; p<0.001$.

\section{Discussion}

This study was conducted to enhance the customer's experience, satisfaction and recommendation by qualitatively and quantitatively analyzing the reviews of airline passengers. For the airline passengers' review data analysis, the first process is extracting keywords by text mining and the second is grouping them using the CONCOR analysis. In addition, the study conducted three consecutive linear regression analyses to understand the relationship between evaluation factors, customer satisfaction, and recommendations presented on the customer review website. Interestingly, six clusters (airline brand, seat comfort, staff, entertainment, ground service and value for money) derived from qualitative semantic network analysis were very similar to the six evaluation factors (seat comfort, staff, F\&B, entertainment, ground service and value for money) that Skytrax is asking customers to evaluate on the website. Therefore, this study quantitatively analyzed the impact relationships among the six evaluation factors of Skytrax, customer satisfaction and recommendation.

The following implications can be suggested by combining qualitative and quantitative analysis:

First of all, the group representing the highest beta coefficient was 'Value for money' in the linear regression analysis, and the related words were 'value', 'price', 'money' and 'cost' through the semantic network analysis. The group contains fewer words than the other group. Even though customers are not frequently mentioning the words related with 'Value for money' on the online review, it is still the most important factor to figure out the customer experience of airlines. According to Brochado, Rita, Oliveira, \& Oliveira [12], 'Value for money' is the key factor as a criterion for positive and negative eWOM. In other words, the airline passengers who classify 'Value for money' as very good or excellent also provide positive eWOM about the airlines' seats, staff, entertainment and food. In addition, Rajaguru [50] examined the effect of value for money and service quality on customer satisfaction and behavioral intention. The results of this study show the same results as most prior studies show that Value for Money has the greatest impact on customer satisfaction and recommendation. Therefore, the airline should focus its most essential tangible and intangible resources on the value for money.

The second highest beta value was 'Staff' in the linear regression analysis, and the related words were 'crew', 'cabin', 'staff', 'attendant', 'smile', 'kind' and 'attitude' through the semantic network analysis. Service performing by staff was an essential key factor to create a good image in the service industry and can still be seen as a part of the company that must be managed at all times to keep up the image of the company. Therefore, it is important to improve the attitude of employees through systematic service training. In addition, providing an environment to enhance employee satisfaction to produce better service to customers can be another way.

Third, the entertainment group derived from the CONCOR analysis includes two factors (Entertainment, F\&B) of passenger evaluation factors on the Skytrax website. Based on the words relating with 'entertainment' were mentioned in the online review text such as 'service', 'food', 'class', 'meal', 'economy', 'quality', 'entertain', 'drink', 'premium', 'breakfast', 'wine', 'movie' and 'dinner' through the semantic network analysis. As the result of regression analysis, evaluation factor on the Skytrax 'Entertainment' had no impact on customer satisfaction and recommendation. However, the other evaluation factor ' $F \& B$ ' had impact on customer satisfaction and recommendation. In particular, the results related to $F \& B$ are significant, and have been found in the recent study as a critical customer satisfaction factor in the Tourism industry [38,51,52]. 
Fourth, 'seat' recorded rank 15 in the top 100 frequent words, and related words were 'flight', 'seat', 'time', 'hour', 'way', 'leg', 'plane', 'journey', 'legroom', 'comfort', 'board', 'room', 'route' and 'option' through semantic network analysis. In addition, 'Seat comfort' had impact on customer satisfaction and recommendation through linear regression analysis. The airline industry has the characteristic of sharing a narrow space with many people, therefore 'Seat comfort' can have a significant impact on customer satisfaction and recommendation. According to the meta-analysis conducted by Lim \& Tkaczynski [53], seating comfort is among the most frequent items mentioned in airline service quality studies. The current results also confirmed that 'Seat comfort' is an important dimension in airline industry.

Lastly, words related to ground service are 'lounge', 'bag', 'bus' and 'ticket'. If the 'Seat comfort' is the indoor physical environment, the 'Ground service' can be the outdoor physical environment to provide a comfortable environment outside of the aircraft. So the airlines need to take care of the condition of the lounge. Especially, the lounge is the space used while waiting, and the time for waiting will be a chance to provide impressive service to the passengers. F\&B provided in the lounge is absolutely important to have quality rest in the lounge. Ground services are shown in linear regression results that have a significant positive influence on both customer satisfaction and recommendation. Airline companies can satisfy passengers and create a positive image by paying attention to the quality of their baggage claim service, the ticketing service required to board the aircraft, and the quality of service provided on limousine buses.

This study presents the academic implication that the study has extended its application area of semantic network analysis. While given the significance of the airline segment in the tourism industry, this study empirically explores among airline experience, customer satisfaction and recommendation by big data analytics. Along the way, the airline has the opportunity to gain an understanding of factors on the review web site, so as to infiltrate into this market and create corresponding marketing strategies for their strong advantages. Understanding online reviews as a manifestation of passengers' experiences can help airlines to identify the main attributes required to achieve positive post-purchase behaviors and to minimize negative intentions. Thus, the online reviews not only provide an efficient way for airlines to collect feedback from airline passengers, but also provide an opportunity to discover how to generate positive intent after the experience. To create a high customer rating and a positive eWOM, airlines should consider 'Seat comfort', 'Staff', 'F\&B', 'Ground service' and 'Value for money'. Among them, 'Value for money' was the most influential attribute in the regression analysis. These key factors may be used to examine the customer satisfaction or to test theoretical models to have a better understanding of airline passenger behavior.

In practice, the analysis of online reviews can be used as a diagnostic tool by managers since customer feedback is important for airlines to improve services and products, and to take action regarding service. The analysis also provides the level of importance of these service attributes so airlines can allocate their resources accordingly. Online review analyses can provide reliable satisfaction assessment for airlines. Airlines can also use this method to analyze their competitors' passenger feedbacks so that they can benchmark themselves against competitors in terms of customer satisfaction. These reviews can be used for sustainable strategic marketing decisions against competitors.

However, this study shows limitations in the area of the study as it focuses on airlines that are mainly handled by the Skytrax (airlinequality.com). Therefore, in future studies, big data analysis using social media data reviews, which is known all around the world, will be a better way to understand consumer trends. Secondly, the collected text was analyzing based on the frequency of individual words, therefore, it is difficult to understand the additional meaning of words. In future studies, further analysis of positives and negatives, and sentimental analysis regarding airline recognition is expected to be carried out to better understand the customer's thoughts and to present stronger strategies to the airline industry.

Author Contributions: H.-J.B. and H.-S.K. designed the research model, analyzed online review data and wrote the paper. 
Funding: This research was supported by Kyungsung University Research Grants in 2019 [grant number KSU-Grants2019]. Additionally, this work was supported by the Ministry of Education of the Republic of Korea and the National Research Foundation of Korea (NRF-2016S1A5A2A03928029).

Conflicts of Interest: The authors declare no conflict of interest.

\section{References}

1. Siering, M.; Deokar, A.V.; Janze, C. Disentangling consumer recommendations: Explaining and predicting airline recommendations based on online reviews. Decis. Support Syst. 2018, 107, 52-63. [CrossRef]

2. Li, W.; Yu, S.; Pei, H.; Zhao, C.; Tian, B. A hybrid approach based on fuzzy AHP and 2-tuple fuzzy linguistic method for evaluation in-flight service quality. J. Air Transp. Manag. 2017, 60, 49-64. [CrossRef]

3. International Air Transport Association. Industry Statistics Fact Sheet. Available online: https://www.iata. org/pressroom/facts_figures/fact_sheets/Documents/fact-sheet-industry-facts.pdf (accessed on 20 May 2019).

4. Beers, B. Investopedia. Available online: https://www.investopedia.com/ask/answers/040715/what-aremajor-expenses-affect-companies-airline-industry.asp (accessed on 3 July 2019).

5. Elliott, K.M.; Roach, D.W. Service quality in the airline industry: Are carriers getting an unbiased evaluation from consumers? J. Prof. Serv. Mark. 1993, 9, 71-82. [CrossRef]

6. Aksoy, S.; Atilgan, E.; Akinci, S. Airline services marketing by domestic and foreign firms: Differences from the customers' viewpoint. J. Air Transp. Manag. 2003, 9, 343-351. [CrossRef]

7. Gilbert, D.; Wong, R.K. Passenger expectations and airline services: A Hong Kong based study. Tour. Manag. 2003, 24, 519-532. [CrossRef]

8. Park, J.W.; Robertson, R.; Wu, C.L. The effect of airline service quality on passengers' behavioural intentions: A Korean case study. J. Air Transp. Manag. 2004, 10, 435-439. [CrossRef]

9. Xu, X.; Liu, W.; Gursoy, D. The impacts of service failure and recovery efforts on airline customers' emotions and satisfaction. J. Travel Res. 2018, 58, 1034-1051. [CrossRef]

10. Zhang, Y.; Cole, S.T. Dimensions of lodging guest satisfaction among guests with mobility challenges: A mixed-method analysis of web-based texts. Tour. Manag. 2016, 53, 13-27. [CrossRef]

11. Liau, B.Y.; Tan, P.P. Gaining customer knowledge in low cost airlines through text mining. Ind. Manag. Data Syst. 2014, 114, 1344-1359. [CrossRef]

12. Saha, G.C.; Theingi. Service quality, satisfaction, and behavioural intentions: A study of low-cost airline carriers in Thailand. Manag. Serv. Qual. Int. J. 2009, 19, 350-372.

13. Brochado, A.; Rita, P.; Oliveira, C.; Oliveira, F. Airline passengers' perceptions of service quality: Themes in online reviews. Int. J. Contemp. Hosp. Manag. 2019, 31, 855-873. [CrossRef]

14. Hunt, J.D. Image as a factor in tourism development. J. Travel Res. 1975, 13, 1-7. [CrossRef]

15. Walker, J.; Baker, J. An exploratory study of a multi-expectation framework for services. J. Serv. Mark. 2000, 14, 411-431. [CrossRef]

16. Tao, S.; Kim, H.S. Cruising in Asia: What can we dig from online cruiser reviews to understand their experience and satisfaction. Asia Pac. J. Tour. Res. 2019, 24, 514-528. [CrossRef]

17. Gretzel, U. Consumer generated content-trends and implications for branding. E Rev. Tour. Res. 2006, 4, 9-11.

18. Kim, H.S.; Noh, Y. Elicitation of design factors through big data analysis of online customer reviews for washing machines. J. Mech. Sci. Technol. 2019, 33, 2785-2795. [CrossRef]

19. Ban, H.J.; Kim, H.S. A study on the TripAdvisor review analysis of restaurant recognition in Busan 1: Especially concerning English reviews. Culin. Sci. Hosp. Res. 2019, 25, 1-11.

20. Browning, V.; So, K.K.F.; Sparks, B. The influence of online reviews on consumers' attributions of service quality and control for service standards in hotels. J. Travel Tour. Mark. 2013, 30, 23-40. [CrossRef]

21. Dellarocas, C.; Zhang, X.M.; Awad, N.F. Exploring the value of online product reviews in forecasting sales: The case of motion pictures. J. Interact. Mark. 2007, 21, 23-45. [CrossRef]

22. Minnema, A.; Bijmolt, T.H.; Gensler, S.; Wiesel, T. To keep or not to keep: Effects of online customer reviews on product returns. J. Retail. 2016, 92, 253-267. [CrossRef]

23. Mudambi, S.M.; Schuff, D. What makes a helpful review? A study of customer reviews on Amazon.com. MIS Q. 2010, 34, 185-200. [CrossRef] 
24. Sotiriadis, M.D.; VanZyl, C. Electronic word-of-mouth and online reviews in tourism services: The use of twitter by tourists. Electron. Commer. Res. 2013, 13, 103-124. [CrossRef]

25. Skytrax. World's Top 100 Airlines 2018. Available online: https://www.worldairlineawards.com/worlds-top100-airlines-2019/ (accessed on 20 March 2019).

26. Adeniran, A.; Fadare, S.O. Relationship between passengers' satisfaction and service quality in murtala muhammed international airport, Lagos, Nigeria. Int. J. Res. Ind. Eng. 2018, 7, 349-369.

27. Jeong, E.Y. Analyze of Airlines Online-reviews: Focusing on Skytrax. J. Tour. Leis. Res. 2017, 2, $261-276$.

28. Yayla-Kullu, H.M.; Tansitpong, P. A critical evaluation of US airlines' service quality performance: Lower costs vs. satisfied customers. J. Manag. Strategy 2013, 4, 1. [CrossRef]

29. Pérezgonzález, J.D.; Gilbey, A. Predicting Skytrax airport rankings from customer reviews. J. Air Transp. Manag. 2011, 5, 335-339.

30. Lohmann, G.; Albers, S.; Koch, B.; Pavlovich, K. From hub to tourist destination-An explorative study of Singapore and Dubai's aviation-based transformation. J. Air Transp. Manag. 2009, 15, 205-211. [CrossRef]

31. Mason, K.J.; Morrison, W.G. Towards a means of consistently comparing airline business models with an application to the 'low cost'airline sector. Res. Transp. Econ. 2008, 24, 75-84. [CrossRef]

32. Park, J.W.; Robertson, R.; Wu, C.L. The effects of individual dimensions of airline service quality: Findings from Australian domestic air passengers. J. Hosp. Tour. Manag. 2006, 13, 161-176. [CrossRef]

33. Gillen, D.; Lall, A. Competitive advantage of low-cost carriers: Some implications for airports. J. Air Transp. Manag. 2004, 10, 41-50. [CrossRef]

34. Davenport, T.H.; Barth, P.; Bean, R. How big data is different. MIT Sloan Manag. Rev. 2012, $54,43$.

35. He, W.; Xu, G. Social media analytics: Unveiling the value, impact and implications of social media analytics for the management and use of online information. Online Inf. Rev. 2016, 40. [CrossRef]

36. Han, S.I.; Kim, T.H.; Lee, J.H.; Kim, H.S. A study on the application of SNS big data to the industry in the fourth industrial revolution. Culin. Sci. Hosp. Res. 2017, 23, 1-10.

37. Oh, C.; Kim, H.S. Understanding of nutrition labelling use and related factors among Korean adults. Culin. Sci. Hosp. Res. 2018, 24, 16-22.

38. Kim, Y.J.; Ban, H.J.; Kim, H.S. An exploratory study on the semantic network analysis of Busan tourism: Using Google web and news. Culin. Sci. Hosp. Res. 2019, 25, 126-134.

39. Jo, A.; Kim, H.S. A comparison of Starbucks between South Korea and U.S.A. through big data analysis. Culin. Sci. Hosp. Res. 2018, 23, 195-205.

40. Shuting, T.; Kang, B.; Kim, H.S. Understanding the food hygiene of cruise through the big data analytics using the web crawling and text mining. Culin. Sci. Hosp. Res. 2018, 24, 34-43.

41. Kim, H.S.; Yim, H.R. An exploratory study on the semantic network analysis of 'Culinary Science \& Hospitality Research' through the Google Scholar. Culin. Sci. Hosp. Res. 2018, 24, 1-10.

42. Shuting, T.; Kim, H.S. A study of comparison between cruise tours in China and USA through big data analytics. Culin. Sci. Hosp. Res. 2017, 23, 1-10. [CrossRef]

43. Oh, C.; No, J.K.; Kim, H.S. Dietary pattern classifications with nutrient intake and body composition changes in Korean elderly. Nutr. Res. Pract. 2014, 8, 192-197. [CrossRef]

44. Hong, J.W.; Park, S.B. The identification of marketing performance using text mining of airline review data. Mob. Inf. Syst. 2019, 19. [CrossRef]

45. Li, H.; Sun, J. Forecasting business failure: The use of nearest-neighbour support vectors and correcting imbalanced samples-Evidence from the Chinese hotel industry. Tour. Manag. 2012, 33, 622-634. [CrossRef]

46. Kim, H.S. A semantic network analysis of big data regarding food exhibition at convention center. Culin. Sci. Hosp. Res. 2017, 23, 257-270.

47. Bonacich, P. Some unique properties of eigenvector centrality. Soc. Netw. 2007, 29, 555-564. [CrossRef]

48. Lee, Y.J.; Yoon, J.H. Exploring ways to utilize SNS big data in the tourism sector. Int. J. Tour. Hosp. Res. 2014, 28, 5-14.

49. Kim, J.J.; Kim, K.; Hwang, J. Self-enhancement driven first-class airline travelers' behavior: The moderating role of third-party certification. Sustainability 2019, 11, 3285. [CrossRef]

50. Lim, S.S.; Tkaczynski, A. Origin and money matter: The airline service quality expectations of international students. J. Hosp. Tour. Manag. 2017, 31, 244-252. [CrossRef]

51. Choi, H.Y.; Kwak, G.H.; Kim, H.S. A positioning study of national food: In perspective of Korean, American, Chinese food tourists. Culin. Sci. Hosp. Res. 2017, 23, 86-94. [CrossRef] 
52. Kim, H.S. An exploratory study on the semantic network analysis of food tourism through the big data. Culin. Sci. Hosp. Res. 2017, 23, 22-32.

53. Rajaguru, R. Role of value for money and service quality on behavioural intention: A study of full service and low cost airlines. J. Air Transp. Manag. 2016, 53, 114-122. [CrossRef]

(C) 2019 by the authors. Licensee MDPI, Basel, Switzerland. This article is an open access article distributed under the terms and conditions of the Creative Commons Attribution (CC BY) license (http://creativecommons.org/licenses/by/4.0/). 